
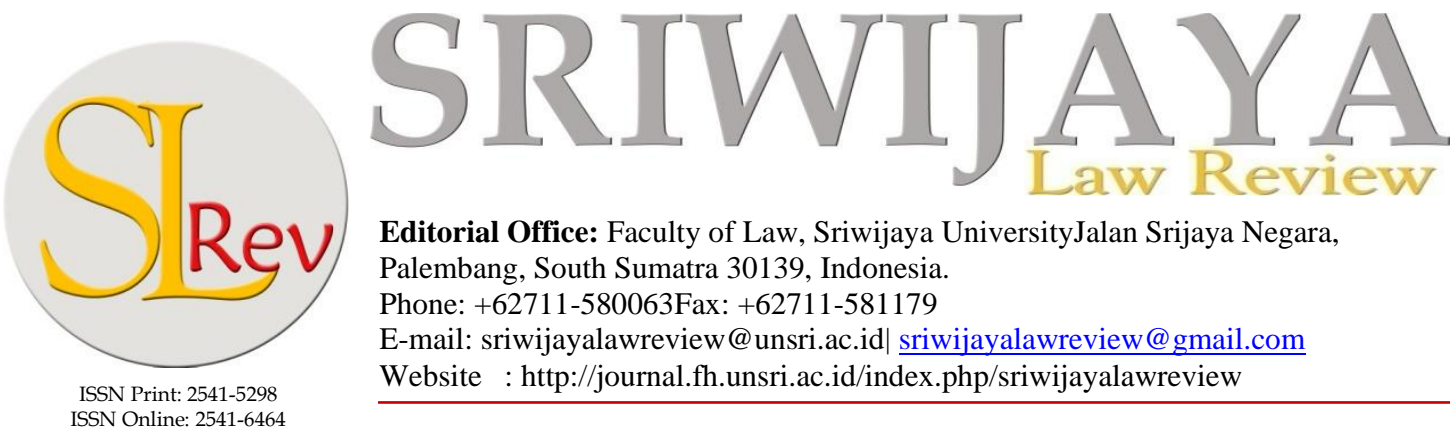

Editorial Office: Faculty of Law, Sriwijaya UniversityJalan Srijaya Negara,

Palembang, South Sumatra 30139, Indonesia.

Phone: +62711-580063Fax: +62711-581179

E-mail: sriwijayalawreview@unsri.ac.id| sriwijayalawreview@gmail.com

Website : http://journal.fh.unsri.ac.id/index.php/sriwijayalawreview

\title{
Strict Liability Principle: Consumer Protection from Hidden Defective Products in Indonesia
}

\author{
$\operatorname{Holijah}^{\mathrm{a}}$ \\ a Faculty of Sharia and Law, Raden Fatah State Islamic University, Indonesia. E-mail: \\ holijah_uin@radenfatah.ac.id
}

\begin{tabular}{|c|c|}
\hline Article & Abstract \\
\hline $\begin{array}{l}\text { Keywords: } \\
\text { Consumer Protection; } \\
\text { Product Liability; Strict } \\
\text { Liability; Tort. } \\
\text { Article History } \\
\text { Received: May 31, 2019; } \\
\text { Reviewed: Jan 16, 2020; } \\
\text { Accepted: Jan 31, 2020; } \\
\text { Published: Jan 31, 2020. } \\
\text { DOI: } \\
\text { 10.28946/slrev.Vol4.Iss2. } \\
\text { 295.pp109-123 }\end{array}$ & $\begin{array}{l}\text { Weak supervision on the standardization of the quality of goods products, } \\
\text { the negative impact of the use of technology, and fraudulent products cause } \\
\text { an increase in hidden defective goods products in the current era of globali- } \\
\text { zation. The phenomenon of the existence of hidden defective products } \\
\text { increasingly demanding the importance of the role of government to } \\
\text { regulate, supervise and control to create a legal construction of product } \\
\text { responsibility for consumers, which normatively does not exist yet. The con- } \\
\text { cept of consumer protection due to hidden defective goods is a new thing } \\
\text { that has never been explained in Indonesian literature. The purpose of this } \\
\text { paper is to analyze the hidden defective products phenomenon, and the legal } \\
\text { basis on the principle of responsibility is applied. Strict liability of produces } \\
\text { due to loss of hidden defective goods products as an effort to protect con- } \\
\text { sumers in Indonesia. This research uses the normative analysis method by } \\
\text { using secondary data as primary data through the statute approach, philo- } \\
\text { sophical approach, and historical approach. The results of this study show } \\
\text { the importance of legal products that can provide consumer rights without } \\
\text { reducing the rights of produces. The need for a legal basis for the product } \\
\text { liability principle with the principle of strict liability to claim the responsibil- } \\
\text { ity of a produces through developing the doctrine of tort as a basis for de- } \\
\text { manding compensation due to hidden defective goods from the outstanding } \\
\text { produces on the market. For this reason, it is recommended as a considera- } \\
\text { tion, namely normative amendment to the law of the Republic of Indonesia } \\
\text { number } 8 \text { of } 1999 \text { concerning consumer protection as a short-term step, } \\
\text { while the long-term step is to issue a special law that regulates the absolute } \\
\text { responsibility of produces due to loss of defective products hidden in the } \\
\text { future. }\end{array}$ \\
\hline
\end{tabular}




\section{INTRODUCTION}

By observing the development of consumers of developing countries in the era free market and globalization ${ }^{1}$ nowadays, on one side, consumers are benefited due to the liberalization as the effect of current free trade. The benefits are the simplicity of goods flow that enter Indonesia and simplicity for consumers to choose and satisfy their needs from the various available products. However, the negative impact is that consumers become the object of produce in gaining maximum profit. ${ }^{2}$

The relationship between producers and consumers is a continuous relationship, whereby the produces heavily depend on the consumers as the costumers. On another side, due to inefficient supervision in the field of product quality standardization, the impact of the technology itself, and the business behavior that influences the consumer society, ${ }^{3}$ especially the developing country was not ready yet and still weak from all the adverse effects of free trade itself. Among them are about the unpreparedness of product legislation that can guarantee consumer protection.

The significance of regulating of consumers rights in Indonesia is stated in the Consumer Protection Laws (UUPK) which is a part of the implemented concept of Pancasila containing the concepts of the rule of law ${ }^{4}$ and the rule of $l a w^{5}$, with the difference in principle lies in its statehood philosophy, which is based on the philosophy of Pancasila. ${ }^{6}$

Along with the process of production and marketing, those are sharpened between suppliers and consumers and also supported by the Book of Civil Code/Book of Commercial Law is liberalism. In contrast, the philosophical doctrine of Pancasila is the people's welfare with a balanced, harmonious, and harmonious life. It has not been included in many laws and regulations which are currently urgently needed.

Furthermore, the government has also committed through various international agreements such as GATT (General Agreement on Trade and Tarif), WTO (World TradeOrganisation), AFTA (Asean Free trade Area), and more to become one of the members who involved in the free trade era. ${ }^{7}$ This free trade requires teamwork between government, produce, and the Indonesian consumer. Based on Article 3 of the UUPK is, "Each individual or business body, either incorporated or not incorporated which is established under the jurisdiction of the Republic of Indonesia, either individual or contracted together through agreements which organize an effort in various economic fields."

The authoritative body plays are an essential role in planning, supervising, and controlling in order to create a legal protection system for maintaining the security of society through protective laws that are fair to both suppliers and consumers. Lacking consumer protection is one

\footnotetext{
Abdul Manan, Aspek-Aspek Pengubah Hukum (Jakarta: Kencana Prenada Media, 2006). Janus Sidabalok, Hukum Perlindungan Konsumen (Bandung: PT. Citra Aditya Bakti, 2006).

Yusuf Shofie, Perlindungan Konsumen Dan Instrumen-Instrumen Hukumnya (Bandung: Citra Aditya Bakti, 2009).

4 Azhary, Negara Hukum Indonesia: Analisis Yuridis Normatif Tentang Unsur-Unsurnya (Jakarta: Universitas Indonesia Press, 1996).

Azhary.

6 Philipus M Hadjon, Perlindungan Hukum Bagi Rakyat Di Indonesia (Surabaya: Bina Ilmu, 1987).

7 Celina Tri Siwi Kristiyanti, Hukum Perlindungan Konsumen (Jakarta: Sinar Grafika, 2008).
} 
of the reasons why the country fails in free trade. ${ }^{8}$ The consumers mentioned are the final consumers who are the users of the product, not the intermediary consumers. ${ }^{9}$

Hence, more information should be provided to consumers. Unfortunately, to hope all consumers have the ability and a big chance to access the information is a complicated matter (consumer ignorance). ${ }^{10}$ It demanded awareness of suppliers to perform their duty and take responsibility, as mentioned in articles of the UUPK (Article 5), primarily related to losses from dangerous products, including hidden defective products.

Based on the United Nations Resolution No. 39/248 of 1984, the rights of consumers that must be protected include the following:

1. The protection of consumers from hazards to their health and safety;

2. The promotion and protection of consumers economical and social interest;

3. Availability of adequate access for consumers to give them the ability to decide their choices according to their wishes and needs;

4. Consumer education;

5. Availability the effort of adequate compensation;

6. Freedom to establish a consumer organization. ${ }^{11}$

However, regardless from all the causes of hidden defective products and no matter how large the dynamics of the market economy to be developed, it still needs intervention state in the form of regulation that will be very influential in the process of economic development and the control of free market itself, ${ }^{12}$ through the application of product liability that accordance with rechtstidee and staatsidee of Indonesian.

Although the law is not a goal, but it is an effort to achieve goals. ${ }^{13}$ According to Salmond, explained by Fitzgerald, the existence of the law itself is aimed at integrating, coordinating, limiting, and protecting various interests in society. ${ }^{14}$ The intended law is consumer protection law system.

Furthermore, based on the principles of responsibility in law that are generally defined as follows:

1. Liability based on a fault is a general principle of civil and criminal law, which states that a person can be liable in general if it is found the element of his error;

2. Presumption of liability is the principle that the defendant is always considered responsible until he can prove his innocence, it means that the burden of proof is on the defendant;

3. Presumption of nonliability only known within the scope of a minimal consumer transaction, no longer applied and lead to the principle of responsible with a limitation of compensation in the form of money;

8 Jagnes Delors, "The Future of Free Trade in Europe and The World," Fordham International Law Journal 18, no. 3 (1994): 715-125.

9 Ahmadi Miru, Prinsip-Prinsip Perlindungan Hukum Bagi Konsumen Di Indonesia (Jakarta: Rajawali Press, 2011).

10 Kristiyanti, Hukum Perlindungan Konsumen.

11 Erman edited by Husni Syawali and Neni Sri Imaniyati Rajagukguk, The Importance of Consumer Protection in the Globalisation Era, in the Book Hukum Perlindungan Konsumen (Bandung: Mandar Maju, 2000).

12 Edy Suandi Hamid and MB. Hendrie Anto, Ekonomi Indonesia Memasuki Milenium II (Yogyakarta: UII Press, 2000).

13 Sudikno Mertokusumo, Mengenal Hukum, Fifth (Yogyakarta: Liberty, 2003).

14 Satjipto Rahardjo, Ilmu Hukum (Bandung: PT Citra Aditya Bakti, 2000). 
4. Strict liability is the principle of responsibility that defines an error, not as a decisive factor;

5. Limitation of liability is the responsibility principle that usually combined with other principles of responsibilities. ${ }^{15}$

From the five legal liability principles mentioned above, in order to provide law protection for consumers who are disadvantaged by the existence of hidden defective products that provide a sense of fairness. Then the need of idea to protect consumers from possible harmful products of hidden defective products, alternatively is to be able applying product liability principle with strict liability principle that accordance with the ideals of country and legal aspirations of Indonesia that is through resolution with development of tort doctrine in general in Article 1365 of present Civil Code which is very important in consumer protection law in Indonesia, especially for hidden defective products. Although explicitly, the concept of strict liability of hidden defective products in Indonesian law has contained in Article 1504 of the Civil Code. ${ }^{16}$

The thought about the need for alternative effort of consumer protection through strict liability principles caused the law hasn't decided yet the error requirement/error as determining factor with a proof burden by the produce, which is unknown in Indonesian legal system, because Indonesia principle of bewijsleer or evidentiary teaching that stating those who postulate it are obligatory to prove the arguments and the events that are referred to, as found in Article 1865 of Civil Code. Article 1865 "Any person who is arguing that he has aright, or in order to affirm his or her own right or to deny rights of others, refers to an event, it is obligatory to prove such right or consent," here is where there is a legal vacuum to provide optimal protection for consumers through regularization in legislation. ${ }^{17}$

The phenomenon of hidden defective products harming consumers can be occurred because business people that produce goods cannot meet the purpose of its manufacture, either due to deliberate, or negligence both in the production process or caused by other things that occur in distribution or because business people do not provide information about how it is used or information about security requirements for consumers. The high consumer consumptive character can also be the cause of the occurrence of fraudulence that done by businessmen in fulfilling consumers' desires. The reluctance of Indonesian consumers to resolve the problem of loss that they experienced due to the actions of businessmen also becomes a culture of consumers in Indonesia. Besides that, product liability regulation is normatively through the principle of strict responsibility of businessmen in Indonesia is only hidden or implicitly not yet normatively clear, as stated in the Law of the Republic of Indonesia Number 8 of 1999 concerning Consumer Protection and also only stated in several different articles.

There are several research results related to this article among others regarding the possibility of hidden defective products that were experienced by consumers, namely the sale and purchase of goods products online, where consumers cannot directly see the condition or physicality of a product that they bought and cannot try the item directly. In online transactions,

15 Shidharta, "Hukum Perlindungan Konsumen," 2000.

16 and R. Tjitrosudibo Subekt, R., Kitab Undang-Undang Hukum Perdata, 10th ed. (Jakarta: PT. Dian Rakayat, 2009).

17 Departemen Pendidikan dan Kebudayaan, Kamus Besar Bahasa Indonesia (Jakarta: Balai Pustaka, 1999). 
consumers certainly hope to get quality and excellent goods following what the businessmen have promised. ${ }^{18}$ There is also other research, namely about the legal consequences that arise from the sale and purchase of goods that have hidden defects and how to settle disputes of sale and purchase of goods that have hidden defects within the scope of the Consumer Protection Law. ${ }^{19}$ Besides, there is also research about defective product problems experienced by consumers so that a legal settlement is needed for consumers who get defective products according to the Law of the Republic of Indonesia Number 8 of 1999 concerning Consumer Protection. ${ }^{20}$ Based on some of the researches results above, there are not contain the legal basis of the principle of product liability in establishing the principle of strict liability as an alternative to claim the responsibility of businessmen through developing the doctrine of unlawful acts as a basis for claiming compensation for the product hidden defects from businessmen that circulated in the market.

With the product liability principle, ${ }^{21}$ with its strict ability, motivated by the imbalance of responsibility between producers and consumers as a form of responsibility of these products, producers are required to be careful of their products. Nowadays, produces is very demanding to know in advance how the interests and past experiences of consumers and the latest information about these products, so that Indonesian produces, can produce qualified products in order to be able to compete in global markets.

Although product liability with strict liability principle in the western legal culture from the state of the Anglo-Saxon system as originator state of liability principle application of produce with strict liability principle, which later undergoes changed in development in some adopted countries including Indonesia.

However, if public's sense of justice and justice requires the other, then based on Article 5 paragraph (1) of Law No. 48 of 2009 about Judicial Power which reads "The Judges and the Judges of Constitution are obliged to explore, follow and understand legal values that live in society," to achieve and fulfill sense of justice especially consumers as disadvantaged parties that fulfilling consumer rights without intent to reduce interest of produce to achieve commercial objectives in their business, because consumer rights are obligations of produces and vice versa, so that the achievement state of Pancasila welfare law provides sense of justice with achievement of consumers' right without reducing the consumers interest to achieve the commercial aim in the form profits.

Based on the background above, then in this paper will be discussed about the legal bases and significance that are the basis for the application of strict liability principle of produces due to the loss of hidden defective products as a consumer protection effort in Indonesia.

\section{RESEARCH METHODS}

18 N.K.S. Dharmawan, "Keberadaan Pemegang Saham Dalam Rups Dengan Sistem Teleconference Terkait Jaringan Bermasalah Dalam Perspektif Cyber Law," Jurnal Magister Hukum Udayana (Udayana Master Law Journal) 4, no. 1 (2015): 15, https://doi.org/10.24843/JMHU.2015.v04.i01.

19 Andreta Tumbelaka, "Wanprestasi Dalam Jual Beli Barang Yang Mengalami Cacat Tersembunyi," Jurnal Lex Privatum 4, no. 5 (2016): 121-29.

20 Ferdricka Nggeboe, "Penyelesaian Hukum Bagi Konsumen Dari Produk Cacat Menurut Undang Undang Nomor 8 Tahun 1999," Legalitas VII (2015): 44-73.

21 Kristiyanti, Hukum Perlindungan Konsumen. 
The type of research of this paper is a normative study, which is a form of legal research that was conducted by studying the literature materials and secondary data only. This research is analytically descriptive in which the result of this study is expected to describe the development of liability of product in initiating strict liability of the development of tort doctrine as a form of consumer protection in the future.

The analysis is done by analyzing the content of analysis to the secondary data and decided conclusion with deductive techniques, namely decided conclusions from general facts to specific ones that are carried out after obtaining a clear, complete, and systematic description of the answer to the problem.

\section{ANALYSIS AND DISCUSSION}

This paper will discuss how to build and initiate product responsibility from hidden defectives products through the principle of strict liability. Therefore, this paper will focus on the following matters:

\section{Legal Protection for Consumer in Indonesia and Law on Consumer Protection}

\section{a. Consumer Protection before Law Number 8 of 1999}

The idea to provide consumer protection is developed from the cases that happened in society. The weak consumer position needed legal protection. Indonesian is required to embrace a new paradigm as an alternative consumer protection effort in the system of consumer legal protection in Indonesia in the future..$^{22}$ Based on the purpose of the legal action itself is giving protection to society. Consumer legal protection, ${ }^{23}$ it should be gotten serious attention, as it is concerning not only the consumers who are getting protection but also the produces who have the same right, because whether the produces or the consumers are by itself have their own right and liability, what is the right of the consumers are the liability of the produce and vice versa.

Consumer protection is giving a description of legal protection given to the consumer in his effort to fulfill its need from the right, which is detrimental to the consumer itself. ${ }^{24}$ Article 1, number 1 law No. 8 of 1999 concerning Consumer Protection (UUPK) is mentioned: "consumer protection is all the effort to ensure legal certainty to provide consumer protection." In the history of humans, including Indonesia, showing that losses that are experienced by consumers of products are often from produces so that they need to be regulated in order not to harm consumers. The form of legal protection that is provided by a country has two characteristics, namely prevention (prohibited) and punitive (sanction). ${ }^{25}$

Therefore, consumers' protection is purposed to regulate the right and obligations of producers and consumers and how to maintain the rights and to carry out these obligations.

22 Holijah and M. Rizal, Examining the Reverse Verification of Compensation Demand for Consumers of Products in the Free Trade Era, Journal of Social Sciences Research, vol. 4, 2018, https://doi.org/10.32861/jssr.412.395.401.

23 Shidharta, "Hukum Perlindungan Konsumen."

24 Sidabalok, Hukum Perlindungan Konsumen.

25 Rafael La Porta, “'Investor Protection and Corporate Governance,"” Journal of Financial Economics 8/10, no. 9 (1999). 
Regulation of rights and obligations and prohibitions for products intended to create a conducive climate of business for the expansion and economical in general, hence the healthy relation between producers and consumers. Article 4 of Law No. 8 of 1999 concerning Consumers Protection (UUPK) which contain the fundamental rights of consumers and consumers liability under the Article 5 of Law No. 8 of 1999 concerning Consumers Protection (UUPK).

To achieve a reciprocal relationship between the produces and the consumers, before the birth of Law No. 8 of 1999 concerning Consumer Protection (UUPK), normatively certainty in legal standing, because it has not summarized in the form of law yet. Meanwhile, the main problem of consumers' protection is to protect the interest of every single human in general that must be protected by the state.

The balance of protection between produces the consumers is a legal function according to Roscoe Pound as a facility of community life control by balancing the interests those are found in the society, in other words, means as social control facility. ${ }^{26}$ Before the birth of consumers protection law, protection effort to the consumers was less felt by the community because they were spread in various laws and regulations, and their implementation was not felt as a protection for consumers. ${ }^{27}$

The joint venture in giving consumers protection before the birth of Law No. 8 of 1999 already provided various legislations, in outline, it could be divided between the private legistation and public legislation. However, the distinctions were not rigid because, in many legalisms, there were found private aspects and also public such as the Law on brands. ${ }^{28}$

The absence of one specific legalism in the consumers protection filed, in fact, they were spread in some regulation about the consumers protection rules, these problems would be discussed further, whether, after the Law No. 8 of 1999 concerning Consumers Protection, the condition of consumers protection in Indonesia has truly achieved or on the contrary or no movement.

\section{b. Consumers Protection Following Law Number 8 of 1999}

The state institution forms the establishment of legislation rules that have various aims and various reasons named legal policy. The legal policy can be differentiated into two dimensions,they are basic policy and law policy. In the process of establishing legislation, law policies are needed to find out the purpose or reasons that arise behind the law of a statutory regulation that is translated into the law itself and the formulation of the particle formulation. ${ }^{29}$

The birth of consumers protection law is also cannot be separated from the policy paradigm priorities and action in political, economic dan establishment of law. ${ }^{30}$ The law

26 Peter Mahmud Marzuki, Pembentukan Hukum Ekonomi Indonesia (Surabaya: Universitas Airlangga. Pick by Edgar Bodenheimer, 1962, Jurisprudence, The Method and Philosophy of Law,Cambridge: Harvard University, 2009).

27 Miru, Prinsip-Prinsip Perlindungan Hukum Bagi Konsumen Di Indonesia.

28 Miru.

29 Hikmahanto Juwana, Politik Hukum Undang-Undang Bidang Ekonomi Di Indonesia, Jurnal Hukum, 2015, http://repository.usu.ac.id/handle/123456789/15356.

30 Juwana. 
policies have political content that can be used for positive or negative things. They are depended on what the legislator want.

The formulation of enactment policy is contained in consideration of weighing or public explanation also on the formulation of the enact or the combined of those three. In Indonesian consumers protection law, the formulation of policy is to provide legal protection to the consumers from the actions of produces that harming the consumers, and also intended to give a legal certainty from the arbitrary actions that harming the product just for the interest of consumers protection. It means even, so it was named consumers protection law; it does not mean the producing interest is not being a concern, mainly because the actor of the business largely determines the national presence. ${ }^{31}$

Although the born UUPK is be expected to maximizing legal protection for consumers in Indonesia, it has not achieved a development like other developing countries yet. The slow development of consumers protection in Indonesia is because of the government action generally is still tends to protect industrial interests which are considered as essential factors in development and also the stage of industrial development is only the beginning stage, unlike the developed countries which have already established their industrial development, so that the implementation of rules is purposed to provide protection to the consumers is less functional, because it is not regulated strictly.

Even so, Law No. 8 of 1999 concerning Consumers Protection has been developed to give a balance between the consumers and the product. Even though there are still many lacks of it regarding the provision that is difficult to implement correctly.

\section{Claims for Compensation of Hidden Defective Product through Liability Principles}

\section{a. The Basis of Compensation Claims in Indonesia's Consumers Protection}

The birth of Law No. 8 of 1999 concerning Consumers Protection (UUPK) is not the beginning and the ending of Indonesian consumers protection problem, as said in consumers protection law for the establishment of implementing regulations from several articles of this law, and the possibility of other laws that provide consumer protection in the future.

The Consumer Protection Law formation is expected to encourage a balance of position between producers and consumers. The fact is the consumers is always the one that harmed, with compensation provisions in the Consumer Protection Law Article 19 Verse (2) in the form of refunds or replacement of goods and/or services of a similar or equivalent value or health care and/or compensation under the provisions of the applicable legislation.

This provision illustrates the development of a balanced position of producers and consumers, even though the provisions have not been sufficiently capable of providing legal certainty that can be done by consumers who suffer losses due to hidden defective products, namely by not including articles that determine the basis of demands for compensation from consumers against produces.

The hidden defective product in this research that is:

Every item that has been added value and usefulness by a businessmen through a production process before being traded which contains disability results in not fulfilling the purpose of

31 Ahmadi and Sutarman Yodo Miru, "Hukum Perlindungan Konsumen” (PT Raja Grafindo Persada, 2004). 
manufacture or cannot be used properly or has reduced function or does not meet consumer safety requirements that are unknown to consumers or from Initially, it was not promised that the product would not be responsible for defective products that had been sold for the defect of the product of the produces, whether the defect was known and/or unknown to the produces which caused the consumer to assume strictly ability for the loss suffered. ${ }^{32}$

In line with the corrective justice from Aristoteles, ${ }^{33}$ that is justice that focuses on the correction of something wrong through the similarities position between business people and consumers to get legal certainty and protection from the government in the regulation of strict liability of produces towards the losses due to hidden defective products.

Hidden defects indicate that the defect occurred because the consumers were not careful about the result of the product that they choose. Hidden defects are the part of the defective product that can be in the form of:

\section{1) Production defect.}

This production error can be distinguished into two-part. The first is errors that include failure of the production process, product installation, failure in inspection facilities, whether due to human negligence or machine irregularity, and similar things. And second, the products intended by the maker, but they are proved to be unsafe in regular use;

2) Design defects.

The design defect is the defect that happened in the preparation product stage. It is consist of design, composition or construction;

3) Inadequate information defects.

This inadequate information is related to the marketing of a product, where the safety of a product is determined by the information that is provided to the users in the form of product labeling, how to used, warning of certain risk or others, so the manufacturers and suppliers can provide guarantee that their products can be used as intended. Thus, the producers are obliged to pay attention to the safety of their products. This does not end only in the circulation of products. ${ }^{34}$

From the types of defective products mentioned above, it cannot be used as a standard to classify the condition of the product as a defective product. Here are several conceptual standards for defining a product as a defective product:

1) Consumer expectations.

The standards of consumer expectation are usually with merchantability standard(eligibility for sale), it means that the product sold must at least be following the usual goals where the product are used;

2) Alleged of seller's knowledge.

That is: Will the seller be negligent in placing their product on the market if the seller knows the dangerous condition on the product?;

32 Holijah, "Tanggung Mutlak Ascetisisme Responsif Subjektif Pelaku Usaha: Konsep Radikal Berbasis Paradigma Hukum Baru Sebagai Alternatif Upaya Perlindungan Konsumen Terhadap Kerugian Akibat Produk Barang Cacat Tersembunyi Di Indonesia” (Sriwijaya University, 2015).

33 Carls Joachim Friedrich, Filsafat Hukum Perspektif Historis (Bandung: Nuansa dan Nusamedia, 2004).

34 H. Duintjer Tebbens, International Product Lability, A Study of Comparativeband International Legal Aspect of Product Liability (Netherlands: Sijthoff \& Noordhoff International Publisher, 1980). 


\section{3) Balance of risks and benefits.}

The majority of courts use risk-benefit analysis to determine defects, especially in cases of design. Risk-benefits can be understood as something similar to the risk of usability. If the cost to change is more significant than the risk, but it is not been changed, then the product is not classified as defective. While if the cost is smaller than the risk, but no changes are made, then the product is classified as defective;

4) State of the Art.

It is similar to unavoidably unsafe defense, whereas the lack of knowledge or the ability to eliminate suspected dangers is used to determine whether a product is truly safe. $^{35}$

By taking into the standard conceptual and considering the danger from hidden defective products, the regulation has not been written yet normatively in Article of UUPK. This condition causes injustice, especially consumers who directly bear the impact of losses. To deal with this phenomenon, what must be done is to clarify the forms of the relationship between producers and consumers for demanding compensation. Here are the forms: 1) What is the relationship between the seller and the consumer base on contractual relationship, it means that both them are preceded by an agreement, so the basis for compensation claims is based on a default, or; 2) If there is no contractual relationship between the seller and the consumer, then the basis for the compensation claim submitted by the consumer is based on tort.

Based on the two basic claims to prosecute producers for their products that are circulated in the market, the foundation for claiming compensation is must be through the tort claim, which is generally regulated in Article 1365 of the Civil Code and based on demands of compensation.

\section{b. Philosophical Basis of the Importance of Compensation Claims}

From both basics for claiming compensation above, if the basis of the claim is the default, it means that the relationship between businessmen and consumers was preceded by an agreement at the beginning. In fact, with the current development of economic and technological trade, not all consumers can engage directly with produce in engagement through written agreements or verbal.

A direct relationship is the absence of an agreement between the consumers and the produces. This condition does not mean that consumers cannot claim compensation towards produce who distribute products that cause losses to the soul, physical, property, or to the product of the item itself.

In the engagement law, the sources are not only an agreement but also from the law. Based on the sources of agreement in the form of laws, they have divided again into laws itself, the laws due to human actions in accordance with the laws, and into those who break the laws. In this case, if it is then associated with the basis of claims of compensation that are not based on the contractual relations with the division of the engagement

35 Jerry J Philips, Product Liability (St Paul Minnesota: West Publishing Company, 1993). 
sources above, then it is deemed to be related to the source of the engagement originating from the tort law.

The effort that can be made to provide consumers protection that is harmed due to hidden defective products is by developing tort doctrines and including liability products with the principle of strict liability. Article 1365 of the Civil Code, mention that "Every tort that causes harm to others, obligating people who because of their mistake cause a loss for others, to compensate the loss." At the beginning, this tort law only interpreted as acts that are against to the law but since Drucker Arrest in the Cohen and Lindenbaum cases that were decided on the $31^{\text {st }}$ January 1919 , there was an expansion of the tort law, such as 1) violate the rights of others; 2) contrary to the legal obligation of the perpetrator; 3) contrary to the decency; 4) not in accordance with appropriateness in community in terms of paying attention to the interests of others. ${ }^{36}$

Although there is a broad understanding of the tort law which contains the meaning of doing (active) or not doing (passive) as long as it is contrary to the meaning of tort in a broad sense, but according to the theory of error, that liability will arise after an error occurs, so that even if there is an error in the provisions of the element does not exist, in fact, there is only a presumption that there is none, so actually, the element of the error is still exist.

Basis of compensation claims based on a default or through a tort, beside the problem of the element of error and the absence of an element of error, and the obligation of the consumer in the form of proof of the burden returned to the postulated, as in Article 1865 of the Civil Code.

The position of consumers who are weak even in financial, knowledge, and experience of a process and distribution of a product especially hidden defective products to prove errors and even shows a causality relationship from a mistake that causes losses that are suffered by the consumers is to complicate. Even it is an impossible thing that consumers can do in general.

This burden proof problem makes consumers reluctant to claim compensation for their losses which endanger in physically and/or mentally, and/or property, and/or environment, and/or the product itself through litigation after the procedure that through nonformal path that can be done directly between producers and consumers by advancing the elements of kinship found a deadlock.

Therefore, it is need legal renewal and the courage of law enforcers by modifying the tort doctrine in product liability with principle of strict liability, by not determining the error factor as a determining factor with the burden of proof on the produces in demanding compensation that were done by consumers, whether the hidden defects are known by the produces or not known, but are not known by consumers, or it is not agreed from the beginning that the produces does not take any liability if there is a loss in the future to the consumers.

36 L.S. Pusponegoro Van J.M. dan Gregor v.d. Burght Dunne, Perbuatan Melawan Hukum (Bandung: Dewan Kerja Sama Ilmu Hukum Indonesia-Belanda, 1987). 
However, there are exceptions, if the defect has already known by consumers or it has been agreed that the risk of defects is borne by the consumers, or for the reasons of force majeure and/or the businessmen can prove the loss suffered by the consumer is not because of the actions of the produces.

It is seen that there is a need for consumers who are also the part of all society to demand a change in the system of liability from the "error" concept to the "risk" concept in demanding compensation. In this condition, it is needed a law that is not only as a tool but also as a means of social renewal, which is a central theme of social engineering through law, but how do we move the social's behavior or to reach the desired conditions through the law, as the opinion of Mochtar Kusumaatmadja. ${ }^{37}$

From the description above, it shows how vital the legal functions are, in general, are:

1) Facilitating function, in this case, includes facilitating so that it is achieved orderliness.

2) Repressive function, in this case, includes the use of law as a tool for the power elite to gain their goals.

3) Ideological function, in this case, includes ensuring the achievement of legitimacy, hegemony, domination, freedom, independence, justice, and others.

4) Reflective function, in this case, the law reflects a mutual desire in society, so that the law must be neutral. ${ }^{38}$

Paying attention to these four statutory functions that must be returned to the primary purpose of the law exists is to fulfill the sense of justice. Sense of justice that wants to be achieved in consumer protection in the principle of strict liability of businessmen towards losses due to hidden defective products is the fulfilled of consumers' rights which are the obligations of produces by not reducing the interest of businessmen in pursuing commercial goals from their efforts to gain profits.

For the Indonesian people, the intended justice is based on Pancasila. Conception and perception of justice must be in accordance with the feeling of a nation. Likewise, in the case of product liability of the produces from the existence of hidden defective products in the market. Law is something that is binding, and if the bond is related to humans, in other words, the bond must reflect a sense of justice. Justice, as a conception, is a justice of sollen's world. However, the sollen's world of justice is also seen in the formulation of the efforts to translate the world of ideas into the sein world (reality).

The role of the state to realize legal protection for all its citizens, both businessmen, and consumers, are aligned with the objectives contained in paragraph IV of the Preamble of the 1945 Constitution of the Republic of Indonesia. The 4th paragraph of the Preamble of the 1945 Constitution confirms:

..., then the national independence is arranged in the an arrangement Republic of Indonesia which is people sovereignty based on; The Belief in the One and only God, on just and civilized humanity, on Indonesian unity and on democratic rules that is guided by the strength of wisdom resulting from deliberation/ representation, so as to realize social justice for all the people of Indonesia.

37 Satjipto Rahardjo, Hukum Dan Masyarakat (Bandung: Angkasa, 1986).

38 Munir Fuady, Teori-Teori Besar (Grand Theory) Dalam Hukum (Jakarta: Prenada Media Group, 2013). 
The basic motivation for the enactment of the UUPK is also that every community, both individually and communally, is a consumer who always benefits the product. This is the background motivation for understanding that the philosophy of national development includes the development of the law that provides protection for consumers to form Indonesian people as a whole.

Therefore, the discourse of principle of strict liability of the businessmen to losses due to hidden defective products as an alternative settlement of compensation of consumers, then normatively for legal certainty must be contained in Law No. 8 of 1999 concerning Consumer Protection as a short-term step, while the long term is by published of a particular law which regulates the strict liability of produces due to the loss of hidden defective products.

The changes preceded by the changes in legislation are generally preceded by the desire in the community to change the law/legislation, which, if the legal changes are successful, will result from an automatically change of mindset and attitude of the community. Therefore, to achieve it in the future, the mindset of consumers must be formed with the awareness of their rights and to obtain their rights.

\section{CONCLUSION}

That the development and the progress of trade economics in the current era of globalization and free-market have positives and negatives impacts. The need for cooperation of all parties who are involved in this process, including the government, producers, and the consumers as a society in broad, to achieve a balance of position between each party.

The foundation as a basis for claiming compensation for the existence of hidden defective products is through the demand of the Tort, which is generally regulated in Article 1365 of the Civil Code and on the basis of demands for default. To further overcome the negative impact of the existence of hidden defective products which are part of defective products in the future as well as the weak position of consumers and a proof system that burdens consumers who have to prove what is postulated is by changing the thinking paradigm of the parties involved such as the state, producers, consumers, and law enforcers to change the liability system from the concept of error to the concept of risk, by developing the doctrine of tort in product liability with the principle of strict liability, because of the weak position of consumers.

The background motivation of consumer protection that becomes its importance sense is the philosophy of national development, including the development of laws that protect consumers from forming Indonesian people as a whole. Consumer protection is intended not to reduce the interests of businessmen to pursue the commercial purpose of their business in the form of obtaining profits so that the fulfilled of consumer's rights which are the obligation of the produces and also to the fulfilled of the produces rights which are the obligations of consumers, so that social justice can be achieved from the development process as stated in the fourth paragraph of the 1945 Constitution of the Republic of Indonesia.

\section{REFERENCES}

Azhary. Negara Hukum Indonesia: Analisis Yuridis Normatif Tentang Unsur-Unsurnya. Jakarta: Universitas Indonesia Press, 1996. 
Delors, Jagnes. "The Future of Free Trade in Europe and The World." Fordham International Law Journal 18, no. 3 (1994): 715-125.

Dharmawan, N.K.S. "Keberadaan Pemegang Saham Dalam Rups Dengan Sistem Teleconference Terkait Jaringan Bermasalah Dalam Perspektif Cyber Law." Jurnal Magister Hukum Udayana (Udayana Master Law Journal) 4, no. 1 (2015): 15. https://doi.org/10.24843/JMHU.2015.v04.i01.

Dunne, L.S. Pusponegoro Van J.M. dan Gregor v.d. Burght. Perbuatan Melawan Hukum. Bandung: Dewan Kerja Sama Ilmu Hukum Indonesia-Belanda, 1987.

Edy Suandi Hamid, and MB. Hendrie Anto. Ekonomi Indonesia Memasuki Milenium II. Yogyakarta: UII Press, 2000.

Friedrich, Carls Joachim. Filsafat Hukum Perspektif Historis. Bandung: Nuansa dan Nusamedia, 2004.

Fuady, Munir. Teori-Teori Besar (Grand Theory) Dalam Hukum. Jakarta: Prenada Media Group, 2013.

Hadjon, Philipus M. Perlindungan Hukum Bagi Rakyat Di Indonesia. Surabaya: Bina Ilmu, 1987.

Holijah. "Tanggung Mutlak Ascetisisme Responsif Subjektif Pelaku Usaha: Konsep Radikal Berbasis Paradigma Hukum Baru Sebagai Alternatif Upaya Perlindungan Konsumen Terhadap Kerugian Akibat Produk Barang Cacat Tersembunyi Di Indonesia." Sriwijaya University, 2015.

Holijah, and M. Rizal. Examining the Reverse Verification of Compensation Demand for Consumers of Products in the Free Trade Era. Journal of Social Sciences Research. Vol. 4, 2018. https://doi.org/10.32861/jssr.412.395.401.

Juwana, Hikmahanto. Politik Hukum Undang-Undang Bidang Ekonomi Di Indonesia. Jurnal Hukum, 2015. http://repository.usu.ac.id/handle/123456789/15356.

Kebudayaan, Departemen Pendidikan dan. Kamus Besar Bahasa Indonesia. Jakarta: Balai Pustaka, 1999.

Kristiyanti, Celina Tri Siwi. Hukum Perlindungan Konsumen. Jakarta: Sinar Grafika, 2008.

Manan, Abdul. Aspek-Aspek Pengubah Hukum. Jakarta: Kencana Prenada Media, 2006.

Marzuki, Peter Mahmud. Pembentukan Hukum Ekonomi Indonesia. Surabaya: Universitas Airlangga. Pick by Edgar Bodenheimer, 1962, Jurisprudence, The Method and Philosopy of Law,Cambridge: Harvard University, 2009.

Mertokusumo, Sudikno. Mengenal Hukum. Fifth. Yogyakarta: Liberty, 2003.

Miru, Ahmadi. Prinsip-Prinsip Perlindungan Hukum Bagi Konsumen Di Indonesia. Jakarta: Rajawali Press, 2011.

Miru, Ahmadi and Sutarman Yodo. "Hukum Perlindungan Konsumen." PT Raja Grafindo Persada, 2004.

Nggeboe, Ferdricka. "Penyelesaian Hukum Bagi Konsumen Dari Produk Cacat Menurut Undang Undang Nomor 8 Tahun 1999.”' Legalitas VII (2015): 44-73.

Philips, Jerry J. Product Liability. St Paul Minnesota: West Publishing Company, 1993.

Porta, Rafael La. "“Investor Protection and Corporate Governance." Journal of Financial 
Economics 8/10, no. 9 (1999).

Rahardjo, Satjipto. Hukum Dan Masyarakat. Bandung: Angkasa, 1986.

. Ilmu Hukum. Bandung: PT Citra Aditya Bakti, 2000.

Rajagukguk, Erman edited by Husni Syawali and Neni Sri Imaniyati. The Importance of Consumer Protection in the Globalisation Era, in the Book Hukum Perlindungan Konsumen. Bandung: Mandar Maju, 2000.

Shidharta. "Hukum Perlindungan Konsumen," 2000.

Shofie, Yusuf. Perlindungan Konsumen Dan Instrumen-Instrumen Hukumnya. Bandung: Citra Aditya Bakti, 2009.

Sidabalok, Janus. Hukum Perlindungan Konsumen. Bandung: PT. Citra Aditya Bakti, 2006.

Subekt, R., and R. Tjitrosudibo. Kitab Undang-Undang Hukum Perdata. 10th ed. Jakarta: PT. Dian Rakayat, 2009.

Tebbens, H. Duintjer. International Product Lability, A Study of Comparativeband International Legal Aspect of Product Liability. Netherlands: Sijthoff \& Noordhoff International Publisher, 1980.

Tumbelaka, Andreta. "Wanprestasi Dalam Jual Beli Barang Yang Mengalami Cacat Tersembunyi." Jurnal Lex Privatum 4, no. 5 (2016): 121-29. 